DOI: https://doi.org/10.28925/2312-5829.2021.412

УДК 378.147:373.011.3-051:78(510)

\title{
ЛЕЙ СЯО
}

Харківський національний педагогічний університет імені

Г.С. Сковороди,

Харків, КНР-Україна,

zhangwei.aspiran@gmail.com, ORCID iD 0000-0003-1750-8567

\section{ХАРАКТЕРНІ ОСОБЛИВОСТІ САМОВИРАЖЕННЯ ПРИ ПІДГОТОВЦІ МАЙБУТНІХ УЧИТЕЛІВ \\ МУЗИЧНОГО МИСТЕЦТВА}

У статті розглянуто питання самовираження майбутніх учителів музичного мистецтва у процесі їх підготовки до подальшої професійної діяльності. Визначено, щчо самовираження пов'язано з культурною обізнаністю та творчими здібностями майбутніх учителів музичного мистеитва. У роботі проаналізовано різні підходи до визначення особливостей самовираження у майбутній музично-педагогічній діяльності здобувачів. На основі наукових здобутків визначено структурні компоненти самовираження майбутніх учителів музичного мистецтва. Така структура включає наступні компоненти: мотиваційноаксіологічний (стійкість мотивів творчої самореалізації; готовність до успішного творчого самовираження у процесі виконавської та інструментальної підготовки); пізнавально-пошуковий (демонструє ефективність та системність музично-інструментальних знань); комунікативно-інтерпретаційний (наявність у студентів здібностей до взаємодії з аудиторією та 3 їх результатами творчого музичноінструментального самовираження; вміння проявляти себе, здійснювати творче саморозкриття і самопрезентацію в процесі виконавської та інструментальної підготовки); рефлексивно-продуктивний (здатність майбутніх учителів музичного мистецтвв реалізувати свої наміри щзодо художнього самовираження в прочесі виконавської та інструментальної підготовки, їх творчі якості, а також їх значення для професійного розвитку, навички самосприйняття при виконанні творчої музичноінструментальної діяльності). Проведено аналіз досвіду самовираження вчителів музичного мистецтва у різних регіонах. Закцентовано увагу на можсливостях використання ичифрових засобів комунікаиії у процесі самовираження в різних умовах.

Ключові слова: майбутні вчителі музичного мистецттва, самовираження, творчість, музика, заклади вищої освіти. 
ISSN Online: 2312-5829 Educological discourse, 2021, № 4 (35)

Вступ. Відповідно до преамбули Загальноєвропейських принципів учительської компетентності та кваліфікації (2010) сучасний вчитель, який хоче викладати, має бути готовим реагувати на виклики суспільства знань, які розвиваються, брати активну участь у ньому та готувати учнів до самостійного навчання протягом усього життя. Таким чином, вони повинні мати можливість рефлексувати над процесами навчання та викладання через постійну взаємодію з предметними знаннями, змістом навчальної програми, педагогікою, інноваціями, дослідженнями, соціальними та культурними вимірами освіти (Common European Principles for Teacher Competences and Qualifications, 2010). Відповідь у контексті підготовки майбутніх вчителів музичного мистецтва та заявлених якостей, якими повинен володіти сучасний вчитель, ми закцентуємо увагу дослідження на культурних вимірах освіти у контексті культурного самовираження.

Зараз люди часто кажуть, що музика «виразна» або що виконавець грає 3 великим виразом. Але що саме це означає? По-перше, можна похвалити виконавця за його музичну чуйність, за те, що він або вона має гостре відчуття того, як повинен бути зіграний уривок. Така похвала часто виражається через «музичність» виконавця. Таким чином, якщо грати «виразно», це означає, що особливі емоційні якості музики - сум, веселість, щастя тощо - широко передаються виконавцем і це дуже важливо, коли ми кажемо про чуттєве сприйняття підростаючого покоління. За словами Bondarenko А. (2020) безумовно важливим для вчителя музичного мистецтва $€$ його професійна підготовка до якої входять компетентності вчителів та його інноваційна спрямованість у педагогічній діяльності. Розвиваючи цю думку, автор наголошує на тому факті, що розвиток особистості відбувається під час професійної підготовки у закладі вищої освіти, так і під час творчої самореалізації в музичному закладі (Bondarenko, 2020). 
Проблеми підготовки майбутнього вчителя музичного мистецтва невіддільні від перебудови всієї системи освіти. Художнє самовираження вчителя музики, як одна 3 форм вираження його особистості, аналізується науковцями-педагогами і з художнього аспекту. Їх все частіше цікавить взаємозв'язок художнього самовираження вчителя та його високої художньої цінності (Elliott, 1995) . Адже художнє самовираження вчителя музики найбільш точно виражає співвідношення високої художньої цінності та індивідуальності. Tavoras V. (2010) визначає художню індивідуальність як інтегральну особливість особистості, що проявляється в музичній діяльності шляхом інтерпретації, оцінки та рефлексивності переживань, творчості, високої художньої цінності та відповідальності.

За словами Yatsian K. (2016) творчий компонент підготовки майбутнього вчителя музичного мистецтва - це та особлива грань, яка відрізняє його від багатьох інших педагогічних спеціальностей. Цей компонент передбачає використання в процесі аудиторної та позаурочної роботи прийомів розвитку творчих здібностей учнів, володіння художньопедагогічною імпровізацією, композиції та організаторських здібностей, елементів акторської гри, розвиненого образного мислення та навичок експресивно-емоційної інтерпретації творів музики. Якість підготовки майбутніх учителів музики значною мірою залежить від рівня актуалізації в них художньо-виконавської майстерності, інтерпретаційних здібностей, знань і навичок 3 метою самостійного оригінального самовираження, іншими словами - самовираження у творчості (Yatsian, 2016).

Заглиблюючись у питання розуміння особливостей самовираження майбутніх учителів музичного мистецтва, потрібно визначити зв'язок цього феномену 3 творчістю, яка є невід'ємною частиною професії вчителя музики. У статті «The essence and component structure of the creative selfexpression of prospective music teachers in the process of performance and instrumental training» за авторством Yatsian К. (2016) розглядається творче 
ISSN Online: 2312-5829 Educological discourse, 2021, № 4 (35)

самовираження майбутнього вчителя музики з позицій феноменологічного підходу як складне, неповторне та багатогранне явище, яке характеризується особливим мотиваційним станом студентів педагогічного університету в процесі виконавського та інструментального навчання. Наявність сформованих спеціальних і професійних знань, виконавські та інструментальні навички студентів визначає здатність майбутнього вчителя музики до творчого самовираження в процесі музичного виконання. Тобто становлення та подальший розвиток досліджуваного явища пов'язане 3 наявністю у здобувачів потреби в спеціальних здібностях, появою нових мотивів, прагнень та змістовних інтересів (Yatsian, 2016).

Розвиваючи питання зв'язку самовираження майбутніх вчителів музичного мистецтва та їх творчості, звернемося до статті «Training of Artistic Skills of the Music Teacher», де розглядаються такі поняття як «творчість» та «художня творчість», засновані на ідеях ряду відомих вчених. Поняття «творчість» визначається відповідно до прагнення художньої особистості до самовираження. Говорячи про структуру та складові творчого процесу, автор виділив чинники, що сприяють розвитку творчих здібностей студентів педагогічно-художніх спеціальностей у процесі проєктування дидактико-художнього підходу. Це також відображається в різноманітності цих факторів: психологічних, педагогічних, дидактичних, художніх. У дослідженні акцентується увагу на тому, що самовираження в художній творчості є потребою особистості, а ця потреба віднесена до естетичних (Tetelea, 2020).

Цінним для нашого дослідження є досвід азіатських країн, оскільки глобалізаційні процеси проявляються в усіх аспектах людської діяльності. У результаті транскордонного обміну інформацією політика шкільної музичної освіти в азіатських країнах розвивала різні тенденції. У статті «Teachers' role in the transition and transmission of culture» досліджується, як ці тенденції використовуються в політиці музичної освіти та як вони 
впливають на вчителів музики в азіатських країнах. У статті стверджується, що останні зміни в політиці у цих країнах відображають їхнє бажання наздогнати глобальну тенденцію цінностей освіти, а не відповідати реаліям вчителів у кожній відповідній країні. Також стверджується, що акцент на культурному різноманітті подвоїв завдання вчителів музики в багатьох азіатських країнах, оскільки тепер вчителям доводиться працювати 3 двома різними типами музики: західною музикою як загальною світовою музичною мовою, а також своєю власною традиційною музикою як музичною мовою, яка є джерелом їхньої національної ідентичності (Ishii \& Shiobara, 2008). Такий підхід має дуальний вплив на становлення вчителів музичного мистецтва, 3 одного боку збільшується варіативність самовираження, а 3 іншого боку розмивається фундамент культурної ідентичності майбутніх вчителів музичного мистецтва.

Мета дослідження. Визначити характерні особливості самовираження майбутніх вчителів музичного мистецтва у процесі фахової підготовки.

Результати. Розглядаючи структурні компоненти та особливості самовираження у майбутніх вчителів музичного мистецтва, звернемося до дослідження Yatsian К. (2016), де автор чітко та зрозуміло виділив чотири компоненти самовираження для педагогів музичного напряму підготовки. Важливо зазначити, що автор розглядає самовираження у невідривному зв’язку з творчістю у процесі навчання інших музичному мистецтву. Відтак структура творчого самовираження майбутніх учителів музичного мистецтва включає мотиваційно-аксіологічний компонент, що відображає стійкість мотивів творчої самореалізації; готовність до успішного творчого самовираження в процесі виконавської та інструментальної підготовки; бажання практично реалізувати власні художні та творчі ідеї; усвідомлення важливості творчої музики та інструментального самовираження для майбутньої професійної діяльності. 
ISSN Online: 2312-5829 Educological discourse, 2021, № 4 (35)

Наступним компонентом структури творчого самовираження майбутніх учителів музики $є$ пізнавально-пошуковий, що демонструє ефективність та системність музично-інструментальних знань. Творче самовираження неможливе без глибокого знання виконавських традицій, жанрів, сучасних музично-інструментальних течій, методологічної обізнаності тощо. Поряд зі спеціальними та професійними музичними знаннями майбутній фахівець потребує загальнокультурних філософських, естетичних, соціальних знань, які дозволяють зрозуміти основні закони історії та теорії виконавської й інструментальної діяльності.

Вищезазначене твердження свідчить про те, що одним із компонентів структури досліджуваного явища є комунікативно-інтерпретаційний, що вказує на наявність у студентів здібностей до взаємодії з аудиторією та з їх результатами творчого музично-інструментального самовираження; вміння проявляти себе, здійснювати творче саморозкриття та самопрезентації в процесі виконавської та інструментальної підготовки; активне творче перетворення художньо-освітньої дійсності під час музичноінструментальної діяльності; навички творчого використання набутих знань та вмінь у музично-інструментальній сфері.

Творча діяльність студентів закладу вищої освіти педагогічного спрямування в процесі виконавсько-інструментальної підготовки при самовираженні визначається їх самоставленням, рефлексією та самопроєктуванням музично-виконавських цілей. Отже, останнім компонентом структури самовираження є рефлексивно-продуктивний. Цей компонент відображає здатність майбутніх вчителів музичного мистецтва реалізувати свої наміри щодо художнього самовираження в процесі виконавської та інструментальної підготовки, їх творчі якості, а також їх значення для професійного розвитку; навички самосприйняття при виконанні творчої музично-інструментальної діяльності; вміння адекватно 
оцінювати результати творчого самовираження та порівнювати їх 3 художньо-творчими очікуваннями (Yatsian, 2016).

Wang X. (2016) пропонує теоретично обгрунтовану модель вираження художньої індивідуальності та самовираження майбутніх учителів музичного мистецтва:

- $\quad$ рефлексивність, що виражається в достовірності інтерпретації музики, оцінці власних здібностей та почутті власної гідності;

- $\quad$ креативність, що виражається в оригінальності інтерпретації музики, оригінальності оцінок та інтенсивності емоційних переживань;

- висока художня цінність, що виражається в гармонійності інтерпретації музики, глибині оцінок та естетичності переживань;

- $\quad$ відповідальність, що виражається в інтерпретації, моральність оцінок і почутті обов'язку.

Помічено, що художня індивідуальність вчителя музики найбільш точно виражає співвідношення високої художньої цінності та індивідуальності. Дослідження Wang X. (2016) показало, що рівень вираження художньої індивідуальності майбутніх учителів музичного мистецтва у музичній діяльності був невисоким через недостатній рівень вираженості інтерпретаційно-оцінних компонентів.

Bondarenko А. (2020) зазначає, що для подолання проблеми творчого самовираження студентів під час професійної підготовки буде недостатньо розробити та впровадити інноваційні педагогічні технології, спрямовані на розвиток творчих здібностей і навичок студентів у навчальному процесі. На практиці важливо розробити та впровадити ефективні педагогічні технології, які орієнтуватимуть на майбутню музично-педагогічну діяльність, відпрацювання проблемних ситуацій навчання, методичну підготовку учнів до використання структурних компонентів евристичного навчання, сучасних комп’ютерних технологій (Bondarenko, 2020). 
ISSN Online: 2312-5829 Educological discourse, 2021, № 4 (35)

Важливим фактором забезпечення ефективної системи самовираження майбутніх вчителів музичного мистецтва $\epsilon$ його зрозумілість та практична направленість. Дієвим засобом практичного втілення самовираження для студентів може стати проєктна діяльність. Відтак збереження змістовних і привабливих для студентів цілей проєктної діяльності (щоб задовольнити потребу в самовираженні) сприяє розвитку компетентності рефлексії та навчання. Особливу увагу слід звернути на характер взаємодії викладача та студентів, що значною мірою зумовлює результати проєктної діяльності. Партнерська (на основі діалогу, відвертості, співробітництва) співпраця з викладачами дозволила студентам «розгорнути ініціативу та особистісне самовираження». Співпраця викладача та студента передбачала обмін концепціями, знаннями та навичками, що спонукає учнів до високих прагнень щодо особистих досягнень та результатів. Слід зазначити, що ролі як студентів, так і вчителів у проєктній діяльності змінилися в позитивному напрямку: від вчителя-вихователя до консультанта здобувача чи навіть рівноправного партнера (Bondarenko, 2020). Такий підхід особливо важливо у контексті розвитку Нової української школи та побудови ефективних зв’язків у діаді вчитель-учень.

Lasauskienė J., Rauduvaitė A., \& Barkauskaitė M. (2015) проводячи свої наукові пошуки, наводять результати якісного контент-аналізу, де робота студентів над індивідуальними музичними проєктами та завдання допомагають їм краще розкрити потенціал музичної діяльності та продумати проведену проєктну діяльність. Розвиток здібностей здобувачів до самооцінки пов'язаний з навчанням самоаналізу, оцінкою власної музичної діяльності, задоволенням потреби самовираження, удосконаленням компетентностей. Виконання проєктних завдань передбачало самостійне залучення здобувачів до музичної проєктної діяльності, навчання планування цілеспрямованої діяльності, прийняття 
різноманітних рішень щодо вибору діяльності та участі, що дозволило їм усвідомити змістовність навчання та його творчий потенціал (Lasauskienė, Rauduvaitè, \& Barkauskaite, 2015).

Важливими предметними компетентностями вчителів музичного мистецтва для китайських студентів за словами Fang Y. (2017) є: розвиток музичного самовираження (виявити особисте розуміння композиції, що виконується, оригінально передати відтінок темпу, динаміки, інтонації композиції, що виконується); розвиток музичних здібностей (застосовувати навички музичної інтерпретації (співати, диригувати, грати на музичних інструментах) у музичній практиці); розвиток особистості (саморозвиток) (будувати кар'єру: планувати та систематично вдосконалювати свою професійну діяльність); мистецькі переживання (відчути потребу самовиразитись під час музики, милуватися композицією, що виконується).

Дослідження Fang Y.(2017) показало, що китайським студентам було найважче коректно використати можливості міміки, погляду, руху для передачі художнього образу композиції (музичне самовираження), застосувати навички музичної інтерпретації (співати, диригувати, грати на музичних інструментах) у практику викладання музики та для інтеграції музичних знань у практику викладання музики (особистості (саморозвиток). Такі результати показують, що китайським здобувачам потрібно більше можливостей для творчого самовираження у контексті їх професійної підготовки до майбутньої музично-педагогічної діяльності.

Обговорення. Самовираження здобувачів музично-педагогічного напряму підготовки - це важливий фактор їх подальшої професійної успішності. Тому у процесі фахової підготовки потрібно звертати особливу увагу на процес розвитку здібностей самовираження.

Розглянемо підготовку майбутніх вчителів музичного мистецтва у piзних регіонах світу. Наприклад, компаративіське дослідження Wong M. (2005) «A cross-cultural comparison of teachers' expressed beliefs about music 
ISSN Online: 2312-5829 Educological discourse, 2021, № 4 (35)

education and their observed practices in classroom music teaching» було проведене за допомогою інтерв’ю та спостереження за повсякденною практикою в класі вчителів музики в початкових школах Ванкувера та Гонконгу. Отримані результати показують, що вчителі музики двох місцевостей мають схожі когнітивні переконання щодо основних елементів музичної освіти. Однак вони дотримуються різних переконань щодо цінності або впливу музичної освіти на психологічний або характерний розвиток учнів. У ході наукового пошуку було виявлено, що вчителі музики у Ванкувері більше зосереджені на здобувачах, ніж їхні колеги в Гонконзі, і це відображається як у навчальній програмі, так і в заходах, обраних для навчання в класі. Хоча обидві групи вчителів роблять однаковий акцент на західній музиці, у Канаді діяльності в класі базується на особистому втіленні та самовираженні учня через приклад вчителя. У Гонконгу, тим часом, музична освіта розглядається як засіб виховання темпераменту учня. У той час як здобувачам у Ванкувері дозволяється висловлювати свої особисті музичні уподобання в класних заняттях, у Гонконзі здобувачі зобов’язані виступати відповідно до встановлених стандартних показників (Wong, 2005).

У наукових доробках Dogani K. (2004) вказано, що вчителі не є вільними особами, але їх вибір, що стосується практики, обмежений обставинами та їхнім сприйняттям цих обставин. Для того, щоб позитивно вплинути на якість навчання дітей, вчителі повинні черпати свої знання 3 цілого ряду їх попереднього досвіду як творчих особистостей, музикантів і вчителів і залучати учнів до творчого музикування та самовираження через музичне мистецтво. Такий підхід неможливий без власної підготовки майбутніх вчителів до культурного самовираження через музику.

Самовираження майбутніх вчителів музичного мистецтва у цифровому просторі має неабиякий потенціал (Ben-Ezzer, 2007). У наш час карантинних обмежень та впровадження елементів дистанційного навчання 
у закладах як вищої, так і середньої освіти цифрові засоби комунікації залишаються вікном можливостей для продовження навчання та розвитку здатностей до самовираження учасників освітнього процесу. Цифрові засоби навчання та комунікації дозволяють у швидкій та зрозумілій формі донести власні напрацювання у музичному мистецтві, проте ризики, пов'язані з якістю фіксації звуку та зображення також присутні . Як правило ані здобувачі, ні вчителі не мають у себе професійного обладання для запису та обробки музичного контенту.

Висновки. Таким чином можна зробити висновок, що самовираження здобувачів вищої музично-педагогічної освіти $є$ вагомим чинником їх подальшого розвитку як у професійному, так і особистісному плані. Однією з основних особливостей самовираження майбутніх вчителів музичного мистецтва є невідривний зв'язок самовираження та творчості, яка може проявлятися у різних аспектах освітнього процесу та у різних формах. Особлива увагу у процесі самовираження відводиться культурній обізнаності та шляхам iї прояву. Тобто у процесі професійної підготовки майбутніх вчителів музичного мистецтва потрібно звертати увагу на те, що їх учні можуть їх не розуміти і завдання педагога постає у підборі дієвих форм та інструментів розвитку власного самовираження й самовираження здобувачів.

Перспективи подальших досліджень полягають у представленні дієвої моделі розвитку компетентності самовираження майбутніх вчителів музичного мистецтва у процесі їх навчання.

\section{СПИСОК ВИКОРИСТАНОЇ ЛІТЕРАТУРИ}

Ben-Ezzer, R. E. (2007). A framework for distance education strategies in digital music education for adults. Nova Southeastern University.

Bondarenko, A. (2020). Technology of Formation of Innovative Identity of Future Teachers of Music Art. EasyChair Preprint, Department of the 
ISSN Online: 2312-5829 Educological discourse, 2021, № 4 (35)

Methodology of musical Education State Pedagogical University Kryvyi Rih, Ukraine, (3188). DOI https://doi.org/10.51647/kelm.2020.4.1.3

Common European Principles for Teacher Competences and Qualifications. http://www.pef.uni-lj.si/bologna/dokumenti/eu-common-principles.pdf

Dogani, K. (2004). Teachers' understanding of composing in the primary classroom. Music Education Research. 6(3). 263-279. https://doi.org/10.1080/1461380042000281721

Elliott, D. (1995) Music Matters: A New Philosophy of Music Education. New York, NY: Oxford University Press.

Fang, Y. (2017). Expression of subject competence of future music teachers at Lithuanian University of Educational Sciences (Master's thesis).

Ishii, Y., \& Shiobara, M. (2008). Teachers' role in the transition and transmission of culture. Journal of Education for Teaching. 34(4). 245-259. https://doi.org/10.1080/02607470802402170

Lasauskienè, J., Rauduvaite, A., \& Barkauskaite, M. (2015). Development of general competencies within the context of teacher training. ProcediaSocial and Behavioral Sciences, 191. 777-782. https://doi.org/10.1016/j.sbspro.2015.04.525

Tavoras, V. (2010). Stimulation of expression of artistic individuality of future music teachers at university (Doctoral thesis).

Tetelea, M. (2020). Training of Artistic Skills of the Music Teacher. Review of Artistic Education. 19 (20). 304-308.

Wang, X. (2016). Artistic self-expression of future music educators and preconditions for its (self-) development (Master's thesis).

Wong, M. (2005). A cross-cultural comparison of teachers' expressed beliefs about music education and their observed practices in classroom music teaching. Teachers and Teaching. 11(4). 397-418. https://doi.org/10.1080/13450600500137182 
Yatsian, K. (2016). The essence and component structure of the creative selfexpression of prospective music teachers in the process of performance and instrumental training. Modern tendencies in the pedagogical science of Ukraine and Israel: the way to integration. 7. 185-191.

\section{ЛЕЙ СЯО}

Харьковский национальный педагогический университет имени Г. С. Сковороды, г.Харьков, КНР-Украина zhangwei.aspiran@gmail.com, ORCID iD 0000-0003-1750-8567

\section{ХАРАКТЕРНЫЕ ОСОБЕННОСТИ САМОВЫРАЖЕНИЯ ПРИ ПОДГОТОВКЕ БУДУЩИХ УЧИТЕЛЕЙ МУЗЫКАЛЬНОГО ИСКУССТВА}

В статье рассмотрено вопросы самовыражения будущих учителей музыкального искусства в прочессе их подготовки $\kappa$ дальнейшей профессиональной деятельности. Определено, что самовыражение связано с культурной осведомленностью и творческими способностями будущих учителей музыкального искусства. В работе проанализировано разные подходы к определению особенностей самовыражения в будущей музыкально-педагогической деятельности соискателей. На основе научных достижений определены структурные компоненты самовыражения будущих учителей музыкального искусства. Такая структура включает следуюшие компоненты: мотивачионно-аксиологический (устойчивость мотивов творческой самореализации; готовность к успешному творческому самовыражению в прочессе исполнительской $и$ инструментальной подготовки); познавательно-поисковый (демонстрирует эффрективность и системность музыкальноинструментальных знаний); коммуникативно-интерпретационный (наличие у студентов способностей к взаимодействию с аудиторией и с их результатами творческого музыкально-инструментального самовыражения, умение проявлять себя, осуществлять творческое самораскрытие и самопрезентацию в прочессе исполнительской $и$ инструментальной подготовки); рефлексивно-продуктивный (способность будущих учителей музыкального искусства реализовать свои намерения по художественному самовыражению в процессе исполнительской и инструментальной подготовки, их творческие качества, а также их значение для профессионального развития, навыки самовосприятия при выполнении творческой музыкально- 
ISSN Online: 2312-5829 Educological discourse, 2021, № 4 (35)

инструментальной деятельности). Проанализировано опыт самовыражения учителей музыкального искусства в разных регионах. Сакцентировано внимание на возможностях ичифровых средств коммуникации в процессе самовыражения в разных условиях.

Ключевые слова: будущие учителя музыкального искусства, самовыражение, творчество, музыка, заведения высшего образования.

\section{LEI SIAO}

H.S. Skovoroda Kharkiv National Pedagogical University, Kharkiv, China-Ukraine zhangwei.aspiran@gmail.com, ORCID iD 0000-0003-1750-8567

\section{CHARACTERISTIC FEATURES OF SELF-EXPRESSION DURING PREPARATION FUTURE TEACHERS OF MUSICAL ART}

The article discusses the issues of self-expression of future teachers of musical art in the process of their preparation for further professional activity. It was determined that self-expression is associated with cultural awareness and creativity of future music teachers. The paper analyzes different approaches to determining the characteristics of self-expression in the future musical and pedagogical activity of applicants. On the basis of scientific achievements, the structural components of self-expression of future teachers of musical art have been determined. This structure includes the following components: motivational-axiological component (stability of motives of creative selfrealization; readiness for successful creative self-expression in the process of performing and instrumental training); cognitive-search component (demonstrates the effectiveness and consistency of musical and instrumental knowledge); communicative and interpretive (students have the ability to interact with the audience and with their results of creative musical and instrumental selfexpression, the ability to express themselves, to carry out creative self-disclosure and self-presentation in the process of performing and instrumental training); reflective-productive component (the ability of future teachers of musical art to realize their intentions for artistic self-expression in the process of performing and instrumental training, their creative qualities, as well as their importance for professional development, self-perception skills when performing creative musical and instrumental activities). The experience of self-expression of music teachers in different regions is analyzed. Attention is focused on the possibilities of digital means of communication in the process of self-expression in different conditions.

Key words: future teachers of musical art, self-expression, creativity, music, institutions of higher education. 
ISSN Online: 2312-5829 Educological discourse, 2021, № 4 (35)

Стаття надійшла до редакиії 19.10.2021

Прийнято до друку 25.11.2021 